Lamia T Rejab

BDS, MSc (Asst. Prof.)

Ihssan F Al-Takai BDS, MSc (Asst. Lec.)

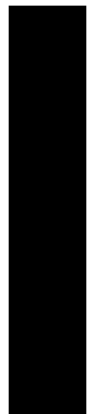

\section{Evaluation the Effect of Different Methods of Disinfection on Surface Roughness of Soft Denture Lining Materials}

Department of Prosthetic Dentistry

College of Dentistry, University of Mosul

Department of Prosthetic Dentistry

College of Dentistry, University of Mosul

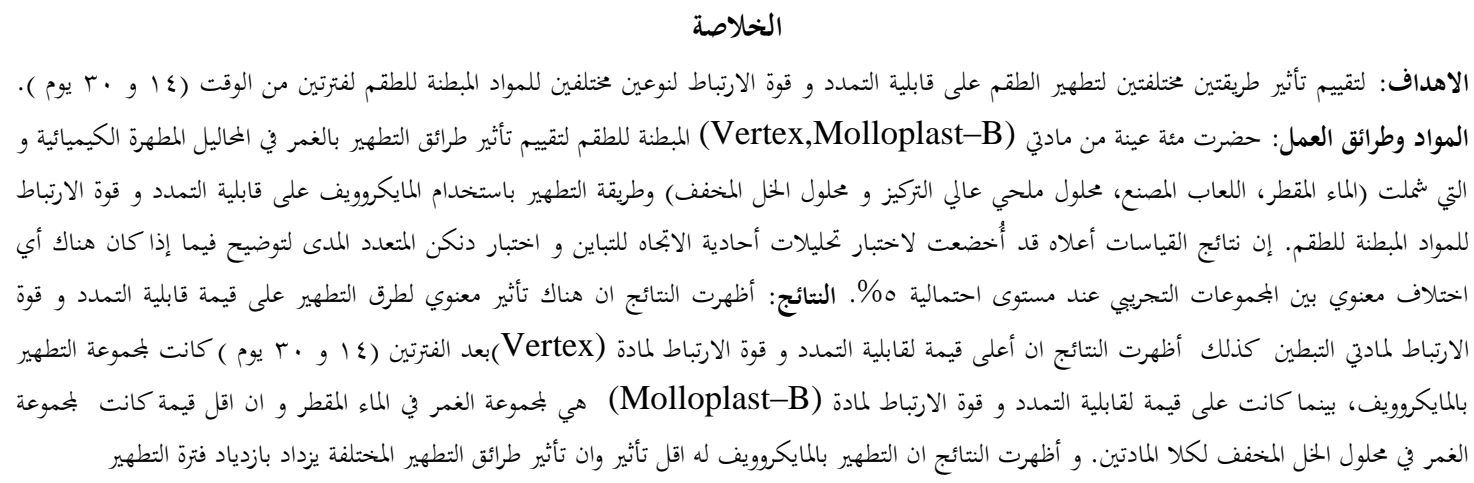

\title{
ABSTRACT
}

Aims: Aim of the study to evaluate the effect of two different disinfection methods for two periods of time on surface roughness of soft denture lining materials (Vertex and Molloplast-B). Materials and methods : The effect of two disinfection methods ,first chemical disinfection method (which include artificial saliva with saturated salt and artificial saliva with vinegar solution), and second microwave method on the surface roughness of soft denture lining materials for two periods of times (14 and 30 days) was evaluated, One hundred samples were prepared. ANOVA and Duncan,s multiple range test were performed to determine the significant difference among the tested groups at $p \leq 0.05 \%$. Results: The results showed that the lowest value of surface roughness (Ra)value after 14 and 30 days for Vertex soft denture lining material was achieved with the microwave group, while the lowest value of surface roughness (Ra)value after 14 and 30 days for Molloplast-B was achieved with the distilled water. The highest value of surface roughness $(\mathrm{Ra})$ for Vertex soft denture lining material was achieved with vinegar after 14 and 30 days., while for Molloplast-B was achieved with vinegar group after 14 days and with salt group after 30 days. Conclusion : The results of T-test Table showed that there were no statistically significant differences in surface roughness(Ra) value between Vertex and Molloplast -B soft denture lining materials after 14 and 30 days except for microwave group after 14 days at $P$ value $\leq 0.05$. Distilled water disinfection has less effect on the property than other chemical disinfection and microwave regimen. The effect of disinfection increase significantly with increasing period of time .

Key words: soft lining material, disinfection, surface roughness $(\mathrm{Ra})$.

Rejab LT, Al-Takai IF. Evaluation the Effect of Different Methods of Disinfection on Surface Roughness of Soft Denture Lining Materials. Al-Rafidain Dent J. 2013; 13(2): 296-304.

Received: 6/2/2012 Sent to Referees: 12/2/2012

Accepted for Publication: 30/4/2012

\section{INTRODUCTION}

Soft denture lining materials are compliant, viscoelastic materials used to form all or part of the fit surface of a denture. They serve to distribute the forces of mastication (functional and nonfunctional stresses)more evenly and to absorb energy(dampening effect) because of elastic behavior. ${ }^{(1)}$ They have been used in dentistry for more than a century, the earliest soft liners were made from natural rubber. ${ }^{(2)}$

Available soft lining materials are based on acrylic resins, fluorocarbon resins, polyolefin resins, and silicone resins. However, the acrylic resin type of soft lining shows good adhesion to dentures, but it cannot be used over an extended period of time because its elasticity vanishes rapidly within several weeks due to the 
oozing-out of plasticizers. The fluorocarbon resin type of soft lining material is limited in terms of water absorption and oozing-out. However, this is not only less effective for relieving pain, but also has difficulty in use because of involving awkward dental operations. The polyolefin resin type of soft lining material, albeit being excellent in elasticity has difficulty in use because of involving very awkward dental operations through which polymerization by heating is carried out with the use of two adhesive materials. The silicone resin type of soft lining material can be used directly in the mouth and so can be handled with ease. ${ }^{(3)}$ Denture hygiene is essential to maintain the service ability of the denture because of esthetic concerns and for prevention of denture-related stomatitis. ${ }^{(4,5)}$ The use of antiseptic and antimicrobial agents, antifungal and microwave irradiation as factors to consider in the treatment of Candida albicans - associated denture stomatitis. Although chemical disinfection seems to be safer to physical properties of denture resins, microwave irradiation has proved to be more effective for denture sterilization and reduction of Candida albicans-infestation than immersion in sodium hypochlorite or chlorhexidine solutions. In relation to surface roughness, microwave energy also modified the surface texture. ${ }^{(6)}$

Aims of the study to evaluate the effect of two different disinfection methods which include the chemical method by the use of artificial saliva, clear vinegar, saturated salt solutions) and microwave method for two periods of time (14 and 30 days) on surface roughness of soft denture lining materials (Vertex and MolloplastB).

\section{MATERIALS AND METHODS}

\section{Mould Preparation (Design):}

The conventional flasking technique for complete denture was followed in the mould preparation. ${ }^{(2)}$ For Vertex (VertexDental B.V, Netherland), the powderliquid ratio was mixed according to the manufacturer's instructions. The soft acrylic denture material dough was placed in the mould of flask for packing and curing. ${ }^{(4)}$ For soft denture lining material Molloplast-B (DETAX DIN EN) was made as a paste material and placed in the mould of flask for packing and curing. Curing was carried out according to the manufacturer's instructions. ${ }^{(2)}$

2. The cycle of immersion and Disinfection methods:

The disinfection methods were performed for the two different soft ling materials (Vertex and Molloplast-B )for two periods of time (14 days and 30days) as in the following:

1. The samples (control group) were soaked in distilled water only at $37^{\circ} \mathrm{C} .^{(7)}$

2 . The samples group of artificial saliva were soaked in distilled water for 8 hours per day at $37^{\circ} \mathrm{C}$, then were immersed in artificial saliva at $37^{\circ} \mathrm{C}$ in incubator (for 16 hours). Artificial saliva was of the following composition: $\mathrm{NaCl}, 0.400 \mathrm{~g} ; \mathrm{KCl}$, $0.400 \mathrm{~g} ; \mathrm{CaCl}_{2} \mathrm{H}_{2} \mathrm{O}, 0.795 \mathrm{~g} ; \mathrm{NaH}_{2} \mathrm{PO}_{4}$, $0.69 \mathrm{~g} ; \mathrm{Na}_{2} \mathrm{~S} \bullet 9 \mathrm{H}_{2} \mathrm{O}, 0.005 \mathrm{~g}$; urea $1.0 \mathrm{~g}$; distilled water, $1000 \mathrm{ml}$. The $\mathrm{pH}$ was then adjusted to 7 or 9 with $\mathrm{NaOH}$ or $\mathrm{HCl}$, and the volume made up to one liter of distilled water. The usage of artificial saliva to produce a setting solution similar to the oral medium. ${ }^{(8)}$

3. The samples group of saturated salt were soaked in distilled water for 8 hours per day at $37^{\circ} \mathrm{C}$, then half an hour per day in saturated salt solution ${ }^{(9)}$ and finally the samples were immersed in artificial saliva at $37^{\circ} \mathrm{C}$ in an incubator for $(15$ and half hours) per day. ${ }^{(10)}$ Saturated salt solution are prepared by the addition of $40 \mathrm{~g}$ of salt to each $100 \mathrm{ml}$ distilled water.

4. The samples group of vinegar solution were soaked in distilled water for 8 hours per day at $37^{\circ} \mathrm{C}$, then half an hour per day in vinegar solution(acetic acid): $\mathrm{CH}_{3} \mathrm{COOH}^{(9)}$ and finally the samples were immersed in artificial saliva at $37^{\circ} \mathrm{C}$ in an incubator for (15 and half hours) per day. ${ }^{(10)}$ Five $(\mathrm{ml})$ of vinegar was diluted in 100 $\mathrm{ml}$ of distilled water. Acetic acid used as household denture cleanser. ${ }^{(9)}$

5.The samples group of microwave were irradiated with Domestic microwave oven (LG,Korea). The recommended microwave energy for sterilization is about $650 \mathrm{~W}$ for $6 \mathrm{~min}^{(11)}$,samples then soaked in distilled water for 8 hours per day at $37^{\circ} \mathrm{C}$, and finally were immersed in artificial saliva at $37^{\circ} \mathrm{C}$ in an incubator for $(15$ and half hours) per day. ${ }^{(10)}$ 
The disinfection solutions and solution of artificial saliva were replaced every day. ${ }^{(10)}$

The PH values of the prepared solutions were measured by using $\mathrm{PH}$ meter device (Figure 1) (PHILIPS, GE, and type PW 94, England) .The PH value of the solution was: Distilled water (7.000), artificial saliva( 7.315), saturated salt solution (7.100) and for vinegar it was (2.603).

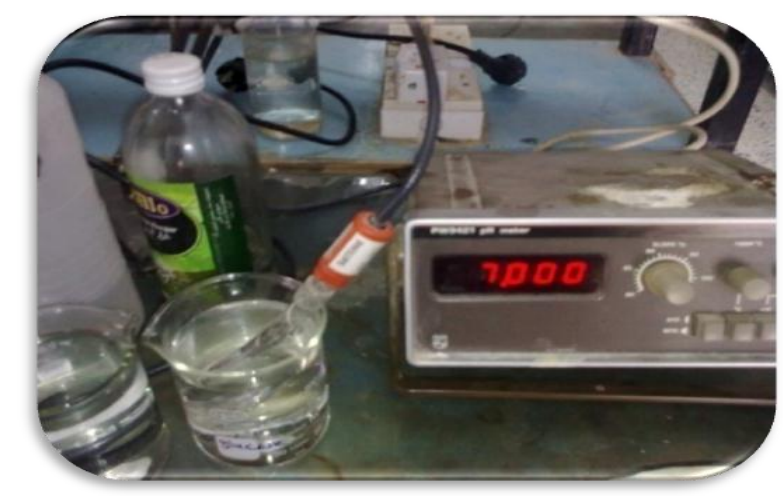

Figure (1): PH meter.

3. Surface Roughness Test:

A stainless steel die (Figure 2) was molded in the flask. The stainless steel die dimensions were $(50 \pm 1 \mathrm{~mm}$ in diameter and $1 \pm 0.05 \mathrm{~mm}$ in thickness). ${ }^{(12,13)}$
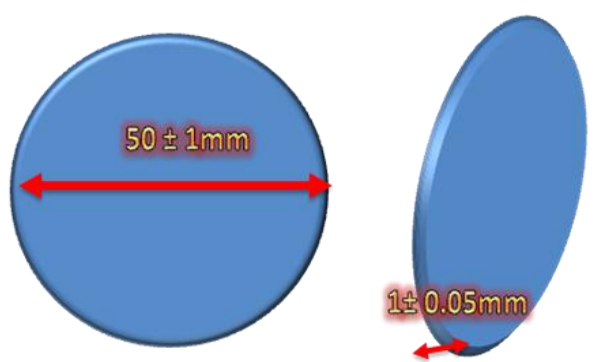

Figure (2): A stainless steel die. ${ }^{(13)}$

After deflasking, the soft lining materials specimens were removed from their stone mould. Then the specimens were numbered and a small hole was prepared in the midline of the upper part for each specimen to allow dispersion by a nylon dental floss in the solutions without contacting each other so that the specimen is surrounded by the solution only. Then the specimens (Figure 3) were stored in distilled water at specified time before each test. ${ }^{(14)}$

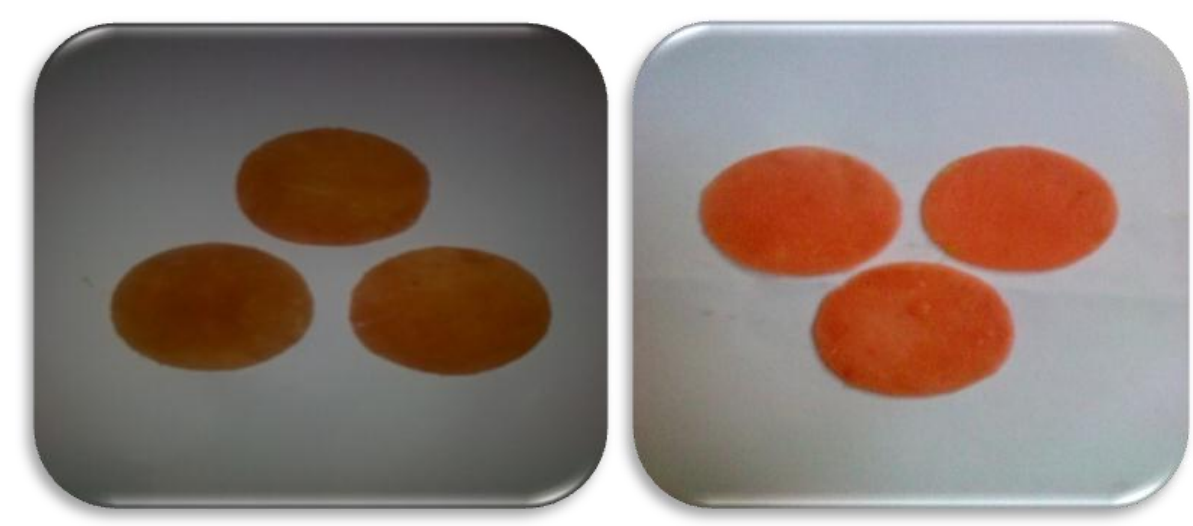

Figure (3): Roughness specimens. 
Fifty specimens were prepared, five specimens to each group. The specimens were immersed in disinfectant solutions and microwave according the recommended plane.

Surface roughness of the specimens was measured using a contact Profilometer Taylor (Hobson Ltd, England) after 14 days and after 30 days of disinfection. Sur- face roughness $(\mathrm{Ra})$ specimens measured in $\mu \mathrm{m}$, three measurements of surface roughness were performed for each sample by using Styles Profilometer (Figure 4) ,as it moves across the specimens surface under constant pressure from mesial to distal direction. The cutoff length of each tracing was $0.8 \mathrm{~mm}{ }^{(15)}$

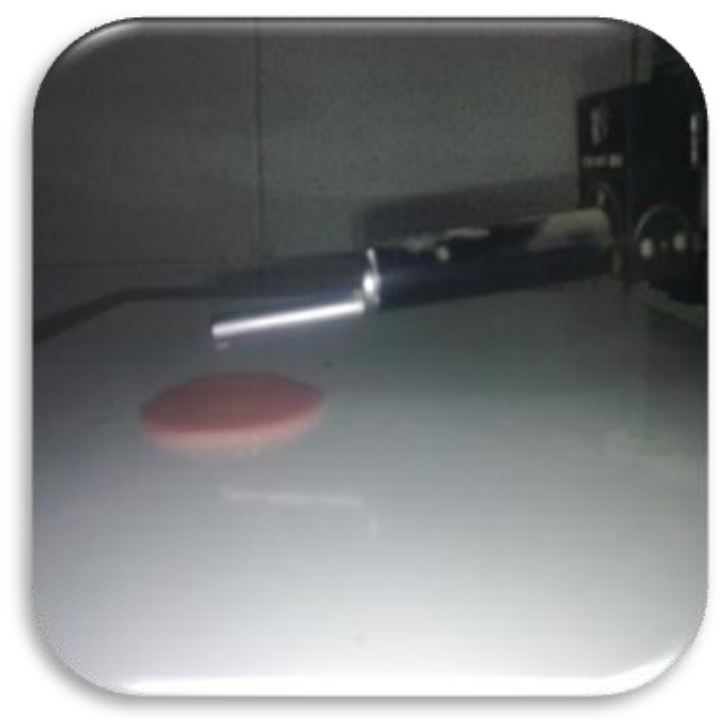

Figure (4): Styles Profilometer.

Surface roughness was determined based on the value of Ra, which represent the average of peaks and depressions on the surface enabling us to evaluating the possibility of bacteria colonizing the area. (16)

Surface roughness parameters. ${ }^{(17)} \mathrm{de}-$ scribed as:

$R$ a: mean of arithmetical average of surface heights.

$\boldsymbol{R}$ max: The magnitude of the peak to -

\section{RESULTS}

The mean and standard deviation of surface roughness $(\mathrm{Ra})$ value of soft den- valley height in all cut-off length.

$\boldsymbol{R z}$ :The average height differences between the five highest peaks and five lowest-valleys within each cutoff length.

Statistical Analysis:Student T- test, One-way analysis of variance (ANOVA) and Duncan's multiple range test were performed to determine the significant difference among the tested groups at $P \leq$ $0.05 \%$.

ture lining materials(Vertex and Molloplast-B)with different methods of disinfection are listed in Table (1). 
Table (1): Mean and standard deviation of surface roughness after 14 and 30 days for both Vertex and Molloplast-B soft denture lining materials among different methods of disinfection at $P \leq 0.05$.

\begin{tabular}{ccccccc}
\hline \multirow{2}{*}{ Solutions } & Materials & No. & \multicolumn{2}{c}{ After 14 days } & \multicolumn{2}{c}{ After 30 days } \\
& & & Mean Ra & S.D \pm & Mean Ra & S.D \pm \\
\hline \multirow{2}{*}{ Distilled water } & Vertex & 5 & 2.453 & 0.279534 & 2.4864 & 0.396165 \\
& Molloplast-B & 5 & 2.0996 & 0.355137 & 2.3458 & 0.340396 \\
\multirow{2}{*}{ Microwave } & Vertex & 5 & 1.7928 & 0.208785 & 2.053 & 0.61781 \\
& Molloplast-B & 5 & 2.4596 & 0.193603 & 3.033 & 0.57345 \\
\multirow{2}{*}{ Artificial saliva } & Vertex & 5 & 2.3396 & 0.386409 & 2.4928 & 0.449434 \\
& Molloplast-B & 5 & 2.5462 & 0.202413 & 2.7798 & 0.201993 \\
\multirow{2}{*}{ Salt } & Vertex & 5 & 2.5864 & 0.199505 & 3.133 & 0.400618 \\
& Molloplast-B & 5 & 2.633 & 0.626848 & 3.233 & 0.39223 \\
\multirow{2}{*}{ Vinegar } & Vertex & 5 & 2.7998 & 0.486941 & 3.5064 & 0.655612 \\
& Molloplast-B & 5 & 2.9398 & 0.6992 & 3.0396 & 0.871184 \\
\hline
\end{tabular}

No.=Number of samples, S.D $=$ Standard deviation

The results showed that the lowest value of surface roughness $(\mathrm{Ra})$ value after 14 and 30 days for Vertex soft denture lining material was achieved with the microwave group $(1.7928 \mathrm{~mm}, 2.053 \mathrm{~mm}) \mathrm{re}-$ spectively.

The results showed that the lowest value of surface roughness $(\mathrm{Ra})$ value after 14 and 30 days for Molloplast-B soft denture lining material was achieved with the distilled water group $(2.0996 \mathrm{~mm}, 2.3458$ $\mathrm{mm}$ ) respectively. The highest value of surface roughness (Ra) for Vertex soft denture lining material was achieved with vinegar after 14 days and 30 days $(2.7998 \mathrm{~mm}, 3.5064 \mathrm{~mm})$ respectively.

The highest value of surface roughness (Ra)forMolloplast-B was achieved with vinegar group after 14 days (2.9398 $\mathrm{mm}$ )and with salt group after 30 days $(3.233 \mathrm{~mm})$.

\section{DISCUSSION}

The $\mathrm{Ra}$ values were most influenced by the time of immersion and the surface condition may be attributed to particle size distribution and chemical composition of polymer powder and the liquid monomer Murata et al. ${ }^{(18)}$

Both resilient materials presented the higher water absorption and solubility when they were immersed in disinfectant solutions and microwave during the time periods these changes may lead to increase roughness data. The result in Table (1) was in agreement with Jin et al, ${ }^{(19)}$ who reported that denture cleanser affected on both acrylic and silicone soft lining materials and the changes in surface roughness due to both immersion time and types of denture cleansers. Results obtained for superficial roughness test are in accordance with Pavaina et al, ${ }^{(20)}$ Silva et al ${ }^{(21)}$ in that there was increase in surface roughness after immersion in vinegar and sodium hypochlorite and sodium perborate. Almost all denture lining materials become rougher, to a greater or lesser extent, by the immersion into denture cleansers Oliveira et al ${ }^{(1)}$; Murata et $a, l^{(18)} \mathrm{Jin}$ et al. ${ }^{(19)}$

Resilient liners are made of materials from several chemical families. These materials undergo chemical changes over time as patients immerse their dentures in denture cleansers. Changes of the surface roughness of the denture lining materials varied depending upon on the changes in the physical properties of denture lining materials appear to depend on their type or composition. Two cycles of microwave irradiation disinfection significantly 
increased the surface roughness of the materials. One possible explanation for these findings is that the high water temperature reached during the disinfection procedure lead to alterations in the surface of the soft liner, thus increasing their surface roughness. After the second cycles of disinfection by immersion in disinfection solutions, all materials demonstrated significant increase in roughness. The results in Table (1) disagree with the results obtained by Pavan et al ${ }^{(22)}$ who evaluated that the silicone and acrylic resin-based liners and observed that the silicone presented surfaces that were smoother than the acrylic resin ones. The roughness difference of the silicone compared to the acrylic resin-based materials is probably related to their consistencies

The results of $t$-test Table (2) indicated that there were no statistically significant differences in surface roughness $(\mathrm{Ra})$ value between Vertex and Molloplast $-\mathrm{B}$ after 14 and 30 days at $P \leq 0.05$ except for microwave group after 14 days.

Table (2): T-test of surface roughness (Ra) after 14 and 30 days for both Vertex and Molloplast-B soft denture lining materials among different methods of disinfection at $p^{*}$ value $\leq$ 0.05, Statistically Significant differences

\begin{tabular}{ccccccccc}
\hline \multirow{2}{*}{ Solutions } & \multicolumn{4}{c}{ After 14 days } & \multicolumn{4}{c}{ After 30 days } \\
& No. & T & Df & $\mathbf{p}^{*}$ value & No. & T & Df & $\boldsymbol{p}^{*}$ value \\
\hline Distilled water & 5 & 1.748 & 8 & 0.723 & 5 & 0.602 & 8 & 0.564 \\
Microwave & 5 & -5.237 & 8 & 0.001 & 5 & 0.2 .6 & 8 & 0.032 \\
Artificial saliva & 5 & -1.059 & 8 & 0.321 & 5 & -1.302 & 8 & 0.229 \\
Salt & 5 & -0.158 & 8 & 0.032 & 5 & -0.399 & 8 & 0.700 \\
Vinegar & 5 & -0.367 & 8 & 0.878 & 5 & 0.957 & 8 & 0.366 \\
\hline
\end{tabular}

$\mathrm{df}=$ Degree of freedom ; No.=number of samples.

The explanation for the results in Tables (1) and (2) is that when the lining materials immersed in cleansing products, a loss of soluble components occurred leaving empty voids or bubbles, these would increased in size and resulted in craters which are responsible for surface roughness. On the contrary, when the specimens were immersed in water for the same periods of time, the weight changes of both resilient materials were lower. Because the loss of soluble components was lower in water these agreed with Garcia et al. ${ }^{(10)}$

The results in Table (2) revealed that there were significantly increase in surface roughness after immersion in disinfection solutions than those specimens immersed in distilled water for the same period.

ANOVA analysis for surface roughness Table (3) revealed that there was a statistically significant differences between the materials after 14 and 30 days for all disinfection methods at $p \leq 0.05$ 
Table (3): ANOVA of surface roughness after 14 and 30 days for both Vertex and MolloplastB soft denture lining materials among different methods of disinfection at $p \leq 0.05$.

\begin{tabular}{|c|c|c|c|c|c|c|c|c|c|c|c|}
\hline & & & 14 & & & & Af & $\cdot 30$ & & & \\
\hline & & SS & Df & MS & $\mathbf{F}$ & $p^{*}$ value & SS & Df & MS & $\mathbf{F}$ & $p^{*}$ value \\
\hline & Between & 2.848 & 4 & 0.712 & 6.497 & 0.002 & 6.695 & 4 & 1.674 & 6.288 & 0.002 \\
\hline ex & Groups & & & & & & & & & & \\
\hline$\sum^{0}$ & $\begin{array}{l}\text { Within } \\
\text { grouns }\end{array}$ & 2.192 & 20 & 0.110 & & & 5.324 & 20 & 0.266 & & \\
\hline & Total & 5.040 & 24 & & & & 12.019 & 24 & & & \\
\hline$\frac{1}{5}$ & $\begin{array}{l}\text { Between } \\
\text { Groups }\end{array}$ & 1.844 & 4 & 0.461 & 2.122 & 0.016 & 2.344 & 4 & 0.586 & 2.095 & 0.019 \\
\hline 产 & $\begin{array}{l}\text { Between } \\
\text { Groups }\end{array}$ & 4.346 & 20 & 0.217 & & & 5.593 & 20 & 0.280 & & \\
\hline$\sum^{e}$ & Total & 6.190 & 24 & & & & 7.937 & 24 & & & \\
\hline
\end{tabular}

$p^{*}$ value $\leq 0.05$,Statistically significant differences, $\mathrm{df}=$ Degree of freedom; MS=Mean square; $\mathrm{SS}=$ sum of square

The result of ANOVA in Table (3) showed statistically significant differences for surface roughness which come in agreement with Jin et al ${ }^{(19)}$ and Silva et al ${ }^{(21)}$ in that the there were statistically significant differences between the materials and both immersion time and the type and $\mathrm{pH}$ of denture cleanser (vinegar, salt) that used in this study.

The result of ANOVA in Table (3) showed statistically significant differences for surface roughness for microwave treatment which come in agreement with
Machado et al ${ }^{(15)}$ who reported the there were statistically significant differences between the materials when irradiated with microwave for more than 2 cycle per day.

Duncan's Multiple Range Test Figure (5) revealed that there were no statistically significant difference of Vertex soft lining material after 14 days of immersion at $\mathrm{p} \leq$ 0.05 in surface roughness except there was a statistically significant difference between microwave group and all other disinfection groups.

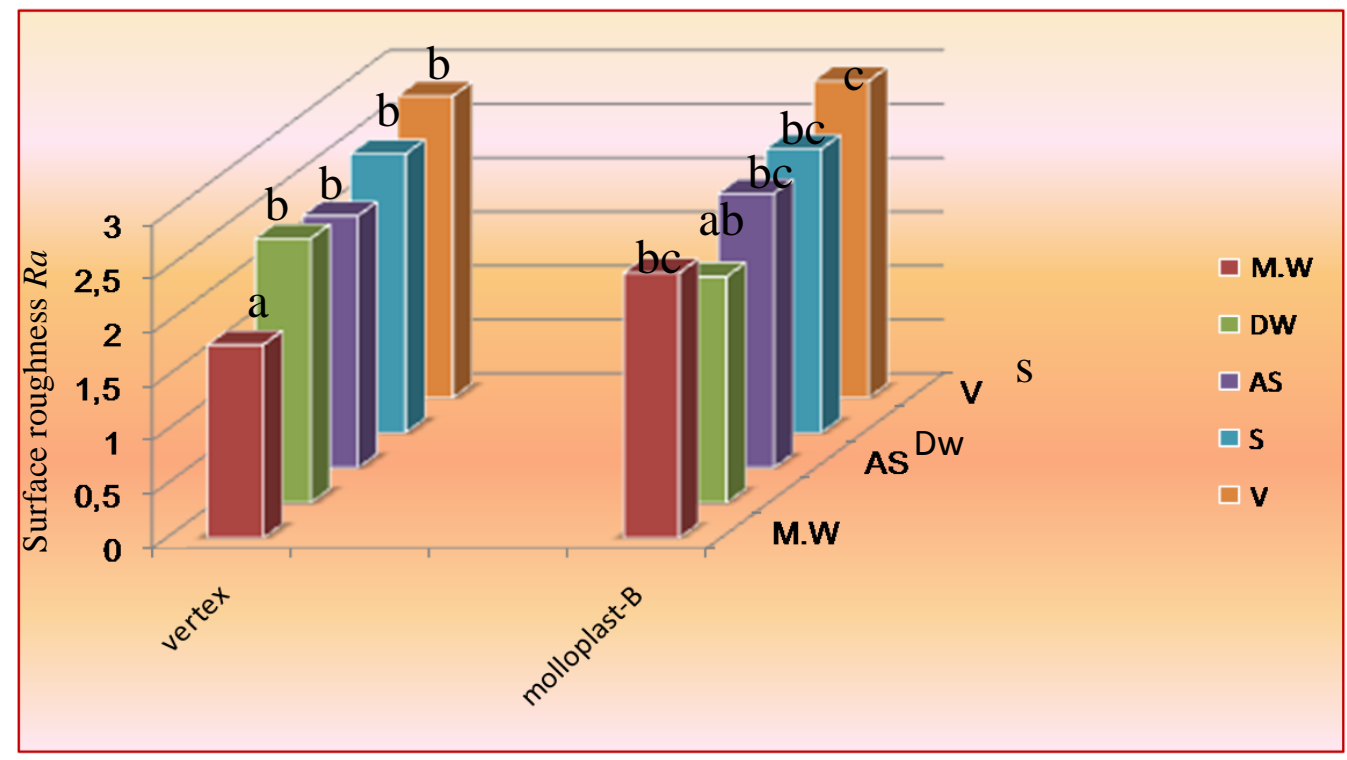

Figure (5): Duncan's Multiple Range Test of roughness test (Ra)value after 14 for both Vertex and Molloplast-B soft denture lining materials among different methods of disinfection at $p \leq 0.05 . *$ means with different letters indicate significant difference at $p \leq 0.05$ 
After 30 days of immersion Figure (6) revealed that there were no statistically significant difference at $p \leq 0.05$ in surface roughness $(\mathrm{Ra})$ value among the control distilled water group and other disinfected tested groups for Vertex soft lining material except that between the control group and vinegar group and between the microwave and salt groups.

Figure (5) revealed that there was no statistically significant difference in sur- face roughness ( $\mathrm{Ra}$ ) value of Molloplast-B soft lining material after 14 days of immersion $p \leq 0.05$, except that between control group and vinegar group.

After 30 days of immersion Figure (6) for Molloplast-B soft lining material revealed that there was no statistically significant difference at $\mathrm{P} \leq 0.05$ in surface roughness $(\mathrm{Ra})$ value between control and all other disinfectant groups, except that between control group and salt group.

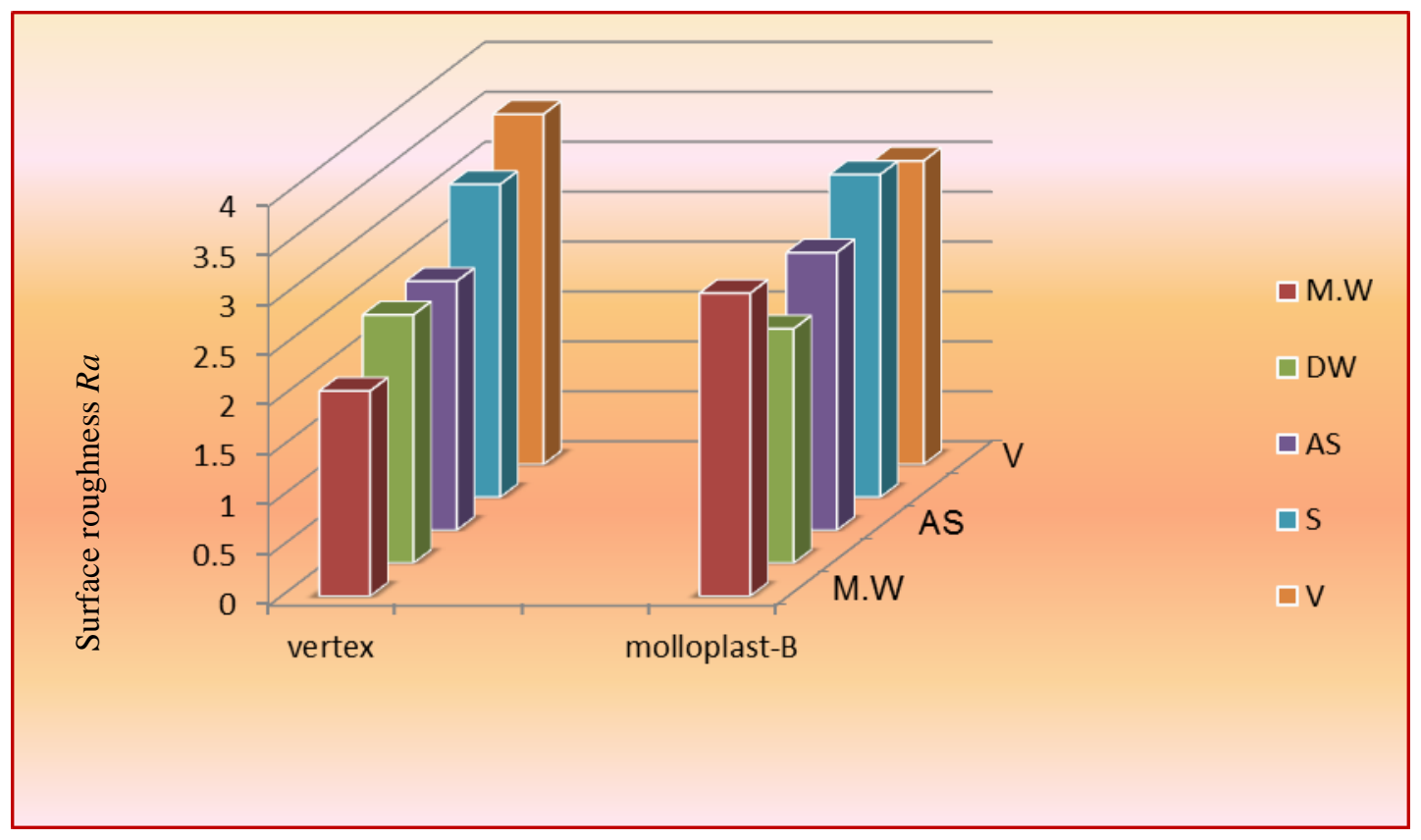

Figure (6): Duncan's Multiple Range Test of surface roghness (Ra) value after 30 for both Vertex and Molloplast-B soft denture lining materials among different methods of disinfection at $p \leq 0.05$.

\section{REFERENCES}

1. Oliveira LV, Mesquita MF, Henriques GE, Consani RL and Fragoso WS . The compatibility of denture cleansers and resilient liners. J Appl Oral Sci. $2006 ; 14$ (4): $286-290$.

2. El-Hadary A and Drummond JL. Comparative study of water sorption, solubility and tensile bond strength of two soft lining materials. $J$ Prosthet Dent.2000;( 83): 356-361.

3. Kamohara JP, Futami JP, Ikeno M, Matsuida-machi JP and Sugahara $\mathrm{H}$ (1997): Classification of soft denture lining materials according to their chemical composition. Corpora-
tion(Tokyo,JP Shin-Etsu Chemical Co., Ltd. (Tokyo, JP) Japanese Dental Science Review Volume 44, Issue 2, October 2008, Pages 128-132

4. Yilmaz H, Aydin C and Turhan B. Effects of disinfectants on resilient denture -lining materials contaminated with Staphylococcus aureus, Streptococcus sobrinus, and Candida albicans. Quintessence Int. 2005 ; 36: 373 -381 .

5. Mese A and Mese S. Effect of microwave energy on fungal growth of resilient denture liner material. Biotechnol. 2007; 21: 91 - 93.

6. Webb BC, Thomas CJ, Willcox MD, 
Harty DW and Knox KW. Candida associated denture stomatitis. Aetiology and management: A review part 3.Treatment of oral candidosis. Aust Dent J. 1998 ; 43:4.O

7. Derafshi R, Khaledi A, and Vojdani M. The effect of two denture cleansers on surface roughness and hardness of a silicone soft liner. J Mash Dent Sch.2009; 33 (1): 33-40.

8. Yanikoglu N and Duymus ZY. Evaluation of the solubility of dental cements in artificial saliva of different $\mathrm{pH}$ values. Dent Mater J.2007; 26 (1): 62 67.

9. Khalil SM . New Denture Cleansers (A Comparative Study). MSc .thesis, University of Mosul.2007.

10.Garcia RC, Leon BL, Oliveira VM and Cury AA. Effect of a denture cleanser on weight, surface roughness and tensile bond strength of two resilient denture liners. J Prosthet Dent. 2003 ; 89: $489-494$.

11. Machado AL, Breeding LC and Puckett AD. Effect of microwave irradiation on the hardness and adhesion of two resilient liners. J Prosthet Dent.2005; 94(2), 183-189.

12.Kazanji MN. The Physical Properties of Resilient Denture Lining Materials M.Sc. Thesis, Faculty Of Medicine, University Of Bristol.1987.

13. Kazanji MN and Watkinson AC. Soft lining materials: their absorption of , and solubility in , artificial saliva. $B r$. Dent. J.1988; 165:91-93.

14.American Dental Association .Guide to dental material and devices $\quad .7^{\text {th }} \mathrm{ed}$. Chicago. USA.1975; Pp.205-208.

15. Machado AL, Breeding LC, Vergani $\mathrm{CE}$ and Perez CL. Hardness and surface roughness of reline and denture base acrylic resins after repeated disinfection procedures. Araraquara Dental School, Sam Paulo State University (UNESP), Araraquara, Sam Paulo,
Brazil; School of Dentistry, University of Mississippi Medical Center, Jackson, Miss J Prosthet Dent. 2009; 102:115-122.

16. Malheiros -Segundo AL, Pisani MX, Paranhos HF, Souza RF and Lovato $\mathrm{CH}$. Effect of a denture cleanser on hardness, roughness and tensile bond strength of denture liners. Braz J Oral Sci. 2008 ; 7 (26): 1596 - 1601.

17.Wang Fu, Chen JH and Wang H. Surface roughness of a Noval dental porcelain following different polishing procedures. Int J Prosthodont. 2009 ; 22: $178-180$.

18. Murata H, Hong G, Li YA and Hamada T. Compatibility of tissue conditioners and dental stones: effect on surface roughness. J Prosthet Dent. 2005 ; 93: $274-281$.

19.Jin C, Nikawa S, Makihira S, Hamada T, Furukawa M and Murata H. Changes in surface roughness and colour stability of soft denture lining materials caused by denture cleansers. $J$ Oral Rehabil. 2003; 30: 125-130.

20.Pavarina AC, Pizzolitto AC and Machado AL. An infection control protocol: effectiveness of immersion solutions to reduce the microbial growth on dental prostheses. J Oral Rehabil. 2003;30:532-536.

21.Silva FC, Kimpara ET, Mancini MN, Balducci I, Jorge AO and Koga-Ito CY. Effectiveness of different disinfectants on removing five microbial species and effects on the topographic characteristics of acrylic resin. J Prosthodont. 2008 ; 17: 627 - 633.

22.Pavan S, Ariolofilho JN, Dos Santos $\mathrm{PH}$ and Mollo FA. Effect of microwave treatments on dimensional accuracy of maxillary acrylic resin denture base. Braz Dent J. 2005 ; 16 (2): 119 123. 